\title{
(2) \\ Ethnobotany of Dacryodes edulis (G. Don) H.J. Lam in Southern Nigeria 1: Practices and applications among the Yoruba speaking people
}

\author{
A. Conrad Omonhinmin
}

\section{Research}

\begin{abstract}
Dacryodes edulis (G. Don) H.J. Lam or eleme is widely used among Yoruba speaking people of Nigeria. The fruit is the major part utilized for food; eaten singly or with a number of other foods. The pulp oil complements common edible oils. Considered rich with medicinal properties; the plant parts is engaged singly or with other plants for treating several illness and diseases including malaria, dermatological, oral and ear conditions, hypertension, leprosy, labor pain, retarded growth and epilepsy in children. Viewed as a symbol of "fruitfulness" and of "peace" the plant parts are employed for both religious and sociocultural activities such as warding off evil spirits, worship of gods, communal festivals, marriage, naming and settlement ceremonies. The wood is used for carpentry, road and shelter construction. The stem exudates act as glue, as well as for production of cosmetics alongside the fruit oil. The tree crown serves for apiculture as well as for shade.
\end{abstract}

\section{Introduction}

Dacryodes edulis (G. Don) H.J. Lam (Burseraceae), has the synonyms: Pachylobus edulis G. Don, Pachylobus saphu (Engl.) Engl., with two varieties; var. edulis, elongated and ellipsoid, usually more that $5 \mathrm{~cm}$ long and 2.5 $\mathrm{cm}$ across and var. parvicarpa Okafor, rounded to more or less conical, usually less than $5 \mathrm{~cm}$ long and $2.5 \mathrm{~cm}$ across (Okafor 1983). Common names include: butter fruit tree, bush butter tree, African pear tree, African plum tree, safoutier (French), eben tree (U.S.A.), and native pear (Africa). D. edulis is a fruit tree, native to Africa. It is an evergreen tree attaining a height of $18-40 \mathrm{~m}$ in the forest but not exceeding $12 \mathrm{~m}$ in plantations. It has a relatively short trunk and a deep-dense crown. The bark is pale grey and rough with droplets of resin. The leaves are compound with 5-8 pairs of leaflets. The flesh of the fruit is dark blue or violet. The tree flowers typically between January and April and bears fruit between May and October (Kapseu \& Tchiegang 1996). The preferential habit of $D$. edulis is a shady, humid dry tropical rain forest, however, it adapts well to variations in soil type, humidity, temperature, and day length. However, it does not do well in the wetter south and drier north. The species probably originates from southern Nigeria, but is now widely distributed in west and central Africa (Leakey \& Ladipo 1996, Okafor 1983).

\section{Ethno-Uses}

African pear (D. edulis) is a well known plant in West Africa. The fruits are edible and the bark, leaves, stem and roots are employed for a variety of purposes (Jirovetz et al. 2003, Neuwinger 2000, Waruhiu et al. 2004). In Nigeria, the main use of $D$. edulis is for its fruit which can be eaten raw, cooked, boiled or roasted. Cooked flesh of the fruit has a texture similar to butter. Oil from the fruit of $D$. edulis is rich in amino acids and triglycerides and

\section{Correspondence}

Omonhinmin A. Conrad, Department of Biological Sciences, College of Science and Technology, Covenant University, PMB 1023, Ota, Ogun State, NIGERIA.

aomoconrad@gmail.com

Ethnobotany Research \& Applications 10:175-184 (2012)

Published: May 02, 2012 
the yield is considerable to augment present oil sources for humans (Ikhouria \& Maliki 2007, Kapseu \& Tchiegang 1996, Kinkela et al. 2006). The seeds contain oil with considerable nutritional value that can be harnessed to supplement feed for household ruminants (Ajiwe et al. 1997, Leakey 1999, Obasi \& Okoli 1993, Omoti \& Okiy 1987). The fruits are gathered for household use as well as for sale in local markets and to some level, the international market (Ajibesin 2011, Awono et al. 2002)

The wood of $D$. edulis has general use for carpentry, tool handles and occasionally for mortars. The stem (resin) exudates sometimes serve as glue, cosmetic components, or are burned for lighting. The tree is used as an ornament and contributes greatly in traditional medicines. The plant's litter fall is known to improve soil quality (Ajibesin 2011, Dalziel 1937).

\section{Ethnobotany}

Traditional people around the world possess unique knowledge of plant resources on which they depend for food, medicine and general utility (Martin 1995). Ethnobotanical studies reveal that cultural attitudes and perspectives on the use and application of bio-resources within their communities constitutes a valuable component in conservation, bio-prospection, domestication and improvement of plant-based products. However, the continuation of this knowledge is endangered when transmission between older and younger generation is no longer happening (Kargiolu et al 2008). The impetus to document ethnobotanical information of indigenous people should increase as we stand to lose such traditions the world over; including the knowledge of how to recognize and use economically valuable wild plant species (Ozgen et al. 2004).

$D$. edulis, particularly within southern Nigeria where it is believed to have originated, is a plant targeted by The World Agroforestry Centre (ICRAF) and National Agricultural Research (NARs) in Nigeria and neighboring countries. The hope is to better identify, characterize and propagate the species for domestication and improvement production programs (IFAD 1999, Simon 1994, Simon \& Leakey 2004).

\section{Yorubaland}

The origins of the Yoruba people is shrouded in mystery with suggestions of distant Egypt or a more ambiguous immortal "Oduduwa" mythology. Their origin seems more likely linked archeologically to the Niger-Benue Confluence of Nigeria, where cultural artifacts similar to those of the Noks are found and a recent analysis links them to the "Bini" people of present Edo State in Nigeria. (Lange 2004).
The Yoruba constitute one of the largest homogenous groups in Africa, popularly referred to as 'Anago' and 'Olukumi' in the past. The Yoruba language is variable with various mutually intelligible dialects. They were predominantly agriculturists and hunters. The Yoruba were also famous for their local industries and artistic work, particularly bronze and brass casting.

In Nigeria, the Yoruba speaking people extend from Kwara/ Kogi states in the North-Central zone to Ondo in the South-South zone making 7 to 8 states in the country that are part of Yorubaland. Yorubaland covers an area of about 70,000 square miles between the two rivers, Niger in the East and Mono in the West. The Yoruba occupy land between latitude $6^{\circ}$ and $9^{\circ}$ North, and longitude $2^{\circ} 3^{\prime}$ and $6^{\circ} 30^{\prime}$ East in west Africa. The landscape of the Yorubaland is crossed with rivers flowing North to South, as well as forests and hills which serve as bulwarks against the infiltration of the interior by the external aggressors. The weather of the area varies from the rainy season to the dry season.

\section{Study Objectives}

This study identifies and examines the use of $D$. edulis among Yoruba people of Southwest Nigeria. The aim is to provide information relevant for participant domestication, environmental development, and improvement programs.

\section{Methods}

\section{Study Area}

The study area of seven states (Figure 1) lies between $3.35^{\circ} \mathrm{N}-5.05^{\circ} \mathrm{N}$ and $6.35^{\circ} \mathrm{E}-8.30^{\circ} \mathrm{E}$ within the humid and sub humid tropical forest. Villages/towns and the local government areas (LGA) where the study was conducted are situated in each state as follows:

- Lagos state: Akpatira (Lagos Island West LGA), Ikoyi town (Eti Osa LGA), Alausa (Ikeja LGA)

- Ogun state: Egbaland (Abeokuta North LGA), ljebu Ode town (ljebu Ode LGA), Abule Ishaga village (Abeokuta LGA), Igbodu village (ljebu Ode LGA), Owu ijebu village (ljebu East LGA), Atiba village (Odogbolu LGA), Ikereku Ikija village (Abeokuta North LGA)

- $\quad$ Ondo state: Owo town (Owo LGA), lyere-Owo village (Owo LGA), ljare - Ologbosere Village (Ifedore LGA), ljagba (Owo LGA)

- Osun state: Iperindo village (Atakunmosa LGA), Okeisa town (Okeisa LGA), ljebu ljesha town (OriAde LGA), llesa town (llesa West LGA)

- $\quad$ Oyo state: Olode village (Akinyele LGA), Tafon village (Ogbomosho South LGA), Ile Otun village (Ogbomosho North LGA), Iware village (Afijio LGA)

- Kwara/Kogi states: Offa (Offa LGA), Ematkwo village (Olomaboro LGA), Kabba town (Kabba LGA), Aiyetoro Gbede village (ljumu LGA) 


\section{Omonhinmin - Ethnobotany of Dacryodes edulis in Southern Nigeria 1: Practices and applications among the Yoruba speaking people}

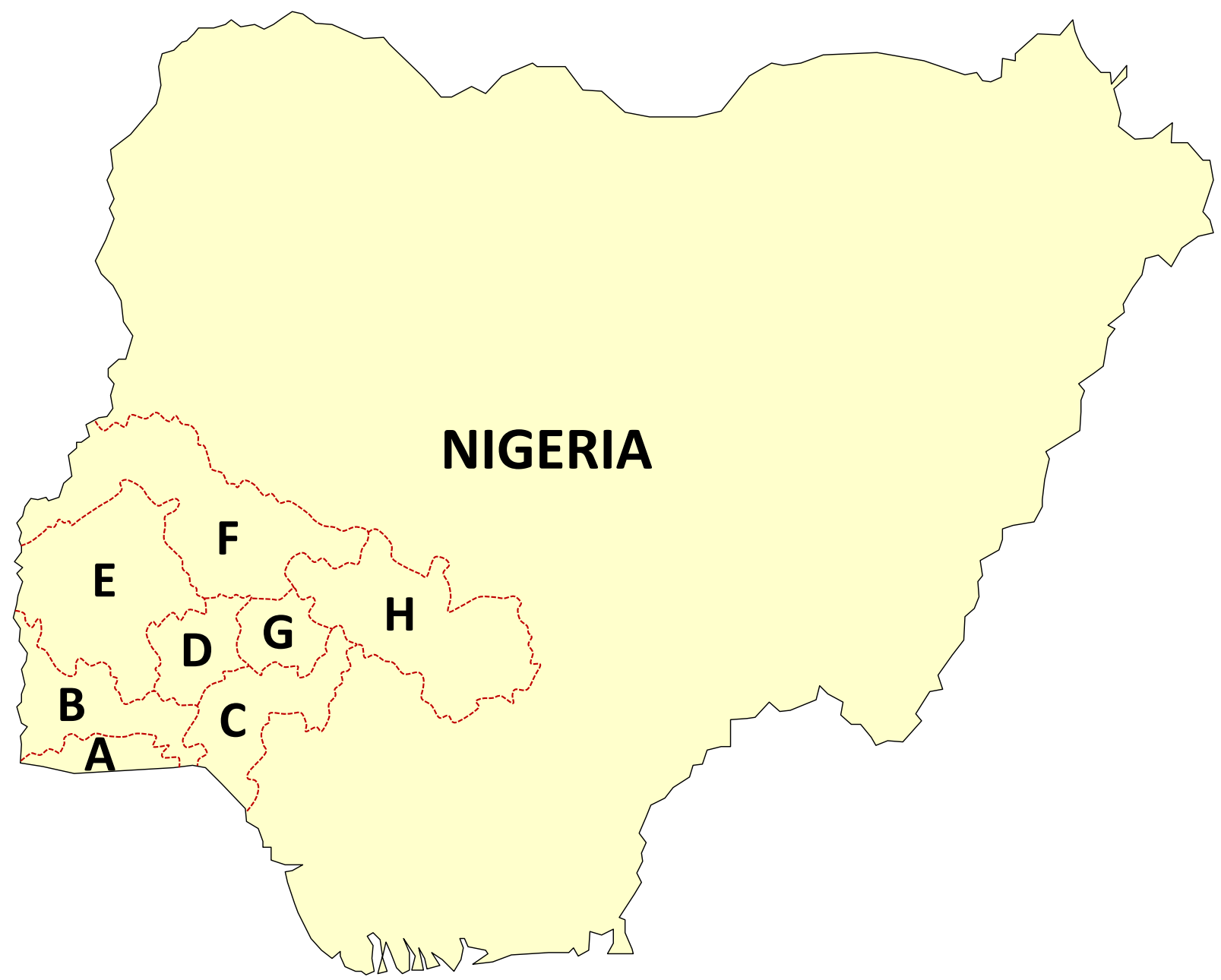

Figure 1. Nigeria with study area of Yoruba speaking states: A) Lagos, B) Ogun, C) Ondo, D) Osun, E) Oyo, F) Kwara, G) Ekiti, and H) Kogi.

- Ekiti state: Ikole village (Ikole LGA), Iyin town and Igede village (Ifelodun Irepodun LGA)

Community heads were approached first to explain to them the researchers' intentions and request recommendations for informants (respondents with most probable knowledge about plants). Family heads and farmers (males) were always approached first. Other members of the family particularly wives could only be interviewed after approval from the family heads. Herbalists and midwives were interviewed based on their status. All Informants gave informed consent to the interviews, and herbalists in particular signed a material transfer forms (MTF)

A semi-structured questionnaire (Martin 1995) was administered and conversations were held with some informants were held with the help of local assistants. These interpreters or local brokers were often detailed by community heads. They were used with the goal to appropriately document and preserve the knowledge on the target species. Informants were interviewed about the importance of the plant: why it is considered important, which parts are used, and for what purposes. The question asked was: "What are the significance, uses, traditions, and stories you know about $D$. edulis?" Complementary questions on other plants were introduced only after the informant had expressed his or her view often in connection with the uses of such plants with $D$. edulis. Observations and guided tours were made of homesteads, markets and shrines, where applicable.

Informants provided details on various applications and practices involving the species, the plant parts used and method of administration. Specimen vouchers (96) and pictures of the plants, scenery, shrines, and markets were collected and deposited at the University of Benin, Benin City.

\section{Results and Discussion}

The survey covered 280 informants (40 respondents per state). The respondents include: 28 herbalist/traditional healers, 28 community leaders, 140 farmer/family heads, 
70 vendors and 14 midwives. $28 \%$ of the sampled informants were females with average age of 42 years. The male informants' averaged 49 years of age.

\section{Ethno-Nomenclature of Dacryodes edulis among the Yoruba}

$D$. edulis is believed to be introduced into the Southwest, Yoruba speaking area of Nigeria, from the Mid-western and Eastern (Igbos) neighbors. The plant has found considerable acceptance and use in the communities where it have been cultivated. It is commonly called eleme or elemi. However, the evolution of other names in certain communities depicts the importance of the plants in such localities. Such names include ibeni by people of Igbodu village; akor by the ljebu ljesha people; orunmwun by the ljagba people; oro by the Okeisa people; and mawe by the Iperindo people.

\section{Food}

$D$. edulis is ordinarily eaten raw or warmed in water, boiled in saltwater for 2-3 minutes, or roasted in hot ashes. Because it is very oily it is usually eaten with yam, corn, cocoyam, rice or bread. Severe boiling is avoided as it tends to rupture the pulp and waste the content. The fleshy mesocarp, after the skin is peeled, can be eaten with bread because of its buttery texture. The fruit pulp is employed as a condiment to make "local" vegetable soup and the ground seeds can serve as a condiment in soups (Table 1). The fruit also yield cooking oil which can compliment common household oil for cooking. Ikhouria and Maliki (2007) and Omoti and Okiy (1987) showed the fruit oil to be of considerable nutritional value. The kernel (seed) serves as food for household ruminant animals such as sheep and goats. $D$. edulis rarely grow in Lagos; nevertheless because of the commercial importance of the city,

Table 1. Dacryodes edulis (G. Don) H.J. Lam parts employed for food, construction and other uses and their preparations in Yoruba-speaking areas of Southwest Nigeria.

\begin{tabular}{|c|c|c|c|}
\hline \multicolumn{2}{|c|}{ Uses } & \multirow{2}{*}{\begin{tabular}{|l|} 
Parts and prepration \\
The fruit pulp yields cooking oil. \\
\end{tabular}} & \multirow[t]{2}{*}{ Citations } \\
\hline \multirow{3}{*}{ 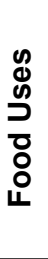 } & Oil & & \\
\hline & Food/condiment & $\begin{array}{l}\text { Fruit is eaten raw, boiled, roasted in hot ashes, cooked in salt water to } \\
\text { form a kind of butter, and with corn yam, cocoyam, rice and bread. The } \\
\text { fruit pulp is employed as a condiment to make "local" vegetable soup. }\end{array}$ & $\begin{array}{l}\text { Ikhouria \& Maliki } \\
2007 \text {, Omiti \& Okiy } \\
1987\end{array}$ \\
\hline & Livestock feed & $\begin{array}{l}\text { The kernel (seed) serves as food for household ruminant animals such } \\
\text { as sheep and goats. }\end{array}$ & \\
\hline \multirow{11}{*}{ 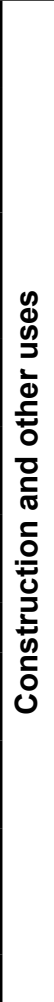 } & $\begin{array}{l}\text { Shade/wind } \\
\text { breaker }\end{array}$ & $\begin{array}{l}\text { The plant is cultivated for shade in association with cocoa or coffee } \\
\text { trees around the house. }\end{array}$ & \\
\hline & $\begin{array}{l}\text { Tools handles/ } \\
\text { shaft/carpentry }\end{array}$ & $\begin{array}{l}\text { The wood has general use for tool handles particularly axe shafts. The } \\
\text { trunk of the plant can be used in making tool handles, some axe shafts } \\
\text { and occasionally for mortars. }\end{array}$ & Dalziel 1937 \\
\hline & Shelters & $\begin{array}{l}\text { Typically finely filed wood from the trees is used in building animal } \\
\text { shelters and crop storage shelters like yam barns, as well as for build- } \\
\text { ing shades, huts and other barns. }\end{array}$ & \\
\hline & $\begin{array}{l}\text { Packaging for } \\
\text { storage }\end{array}$ & Leaves are used for packaging stuff for storage. & \\
\hline & Apiculture & $\begin{array}{l}\text { The tree serves as good site for apiculture (bees farming) due mainly } \\
\text { to its sizeable crown. }\end{array}$ & \\
\hline & $\begin{array}{l}\text { Local soap and } \\
\text { balm production }\end{array}$ & $\begin{array}{l}\text { Oil is extracted from the fruit pulp and added to soap and balm formu- } \\
\text { lations. }\end{array}$ & \\
\hline & Thickeners & Added to other medications and cosmetics. & Ekpa 1993 \\
\hline & Glue & $\begin{array}{l}\text { The stem exudates can serve as glue for non-heavy duty needs, as } \\
\text { well as being apply to woody surfaces to prevent insect infestation. }\end{array}$ & \\
\hline & Road construction & $\begin{array}{l}\text { The trunk of the plant is used for communal construction of new roads } \\
\text { and the repair of old ones. }\end{array}$ & \\
\hline & Fuel/firewood & $\begin{array}{l}\text { The dried twigs, branches and trunk serves well for firewood and the } \\
\text { stem exudate is used as fuel for lighting local-made outdoor lamps } \\
\text { and torches. }\end{array}$ & $\begin{array}{l}\text { Ayuk et al. 1999, } \\
\text { Ekong \& Okogun } \\
1969\end{array}$ \\
\hline & Manure & The leaf litter serves for improving soil fertility. & \\
\hline
\end{tabular}




\section{Omonhinmin - Ethnobotany of Dacryodes edulis in Southern Nigeria 1: Practices and applications among the Yoruba speaking people}

the fruit is heavily traded and a great deal is consumed with no particular cultural attachment.

\section{Construction and Other Uses}

Among the people of Ikereku Ikija, the Abule Ishaga and ljebu Ode, as well as the people of Iyin and Ikole towns the plant is cultivated for shade in association with cocoa or coffee trees. It also serves as a wind breaker around houses.

The wood has general use for tool handles particularly axe shafts and is suitable for carpentry. Typically finely filed wood from the trees is used in building shelters and barns. The trunk and large branches are employed for light tool handles such as cutlasses, axes, etc., as well as for light weight carpentry work. In ljare (Ologbosere) village, $D$. edulis wood can be used to make handles of farming implements as well as for carpentry (Dalziel 1937). The stem exudates can serve as glue or as fuel for outdoor torches/ lamps (Table 1). Ekong and Okogun (1969) and Ayuk et al. (1999) working in Cameroon reported similar findings.
The wood and leaves are generally included among the building materials used to construct large farm outbuildings (storage houses) for storing grains, yams and other farm products, or as livestock shelter. In Owo town, the wood is used for mending old roofs of barn houses. The trunk of the plant is employed for the communal construction of new roads and the repair of old ones.

The tree serves as a good site for apiculture, due mainly to its sizeable crown. In the places where the plant is cultivated, particularly when alongside cocoa and coffee, the leaf litter of the plant is prized for its replenishing effect on the soil, hence it is considered a good manure. The fruit oil is drained for local soap and balms production;

\section{Ethnopharmaceutical - Medicinal/Herbal Uses}

Leaves: The leaves or bark are boiled in pap water (decanted water from ground fermented grains) and administered to children to treat retarded growth and epilepsy (Table 2). The leaves (and roots) are boiled either singly or with lemon grass (Cymbopogon citratus (DC.) Stapf) and administered orally for the treatment of hypertension.

Table 2. Medicinal/herbal uses of Dacryodes edulis (G. Don) H.J. Lam parts, preparations and applications in Yorubaspeaking areas of Southwest Nigeria, with earlier corresponding references.

\begin{tabular}{|c|c|c|}
\hline IIIness/uses & Parts and prepration & Citations \\
\hline $\begin{array}{l}\text { Ecto-parasite infection, } \\
\text { Skin diseases and disor- } \\
\text { ders. }\end{array}$ & $\begin{array}{l}\text { Resin exudates used singly or mixed with local oils (e.g., palm } \\
\text { oil), appled topically to the skin. Crushed leaf liquid is applied } \\
\text { to affected areas. }\end{array}$ & $\begin{array}{l}\text { Dalziel 1937, Hutchin- } \\
\text { son et al.1963, Okwu \& } \\
\text { Nnamdi } 2008\end{array}$ \\
\hline Skin smoothening (lotion) & Pulp oil and with avocado pulp, palm kernel oil and spices. & $\begin{array}{l}\text { Ayuk et al. 1999, Ekpa } \\
1993\end{array}$ \\
\hline Beri beri and rickets & Root boiled with other herbs and taken orally. & \\
\hline Wounds, bruises, cuts & $\begin{array}{l}\text { Resin exudates, fruit oil, or powdered bark in oil topically is } \\
\text { applied. Crushed leaf liquid is applied to affected areas. }\end{array}$ & \\
\hline Hypertension & $\begin{array}{l}\text { Boiled leaves or roots with or without lemon grass or African } \\
\text { locust bean bark or leaves is taken. }\end{array}$ & \\
\hline $\begin{array}{l}\text { High blood pressure/ } \\
\text { peptic ulcer }\end{array}$ & $\begin{array}{l}\text { The leaves boiled singly or with lemon grass, or pulp oil is } \\
\text { administered. }\end{array}$ & \\
\hline General body weakness & $\begin{array}{l}\text { Pulp oil and boiled leaf decoction, or resin exudates with or } \\
\text { without local oils (e.g. palm oil), are applied topically. }\end{array}$ & \\
\hline Stress & Dried, powdered seed hot water infusion (tea) is taken. & \\
\hline Thickeners & Added to other medications and cosmetics. & Ekpa 1993 \\
\hline $\begin{array}{l}\text { Toothache, gum problem, } \\
\text { gargle, mouthwash, tonsil- } \\
\text { litis, earache }\end{array}$ & Bark or leaf decoction is applied. & $\begin{array}{l}\text { Ajibesin 2008, Burkill, } \\
\text { 1985, Igoli et al. } 2005\end{array}$ \\
\hline General pain & $\begin{array}{l}\text { Pulp oil or resin exudates are applied topically with or without } \\
\text { local oils (e.g., palm oil). }\end{array}$ & \\
\hline Arthritis and stiffness & $\begin{array}{l}\text { Resin exudates used singly or mix with local oils (e.g., palm } \\
\text { oil), apply topically to the skin, pulp oil. }\end{array}$ & \\
\hline $\begin{array}{l}\text { Internal body heat/ mus- } \\
\text { cles relaxation/ high fever }\end{array}$ & A decoction of boiled leaves is used. & \\
\hline
\end{tabular}




\begin{tabular}{|l|l|l|}
\hline Illness/uses & Parts and prepration & Citations \\
\hline Malaria & $\begin{array}{l}\text { Boiled leaves or bark with elephant grass or other plant ma- } \\
\text { terials is used. }\end{array}$ & \\
\hline $\begin{array}{l}\text { Retarded growth in } \\
\text { children, epilepsy }\end{array}$ & $\begin{array}{l}\text { Leaves or bark are boiled in pap water (water from grinded } \\
\text { fermented maize). }\end{array}$ & \\
\hline $\begin{array}{l}\text { Muscle pain/ stiffness } \\
\text { (e.g., cramps) }\end{array}$ & $\begin{array}{l}\text { Stem exudates, fruit oil, or powdered bark in oil are applied } \\
\text { topically. }\end{array}$ & \\
\hline $\begin{array}{l}\text { Ease labor pains/safe de- } \\
\text { livery }\end{array}$ & $\begin{array}{l}\text { Dried, powdered leaves are boiled with local oils and other } \\
\text { materials, then administered. }\end{array}$ & \\
\hline $\begin{array}{l}\text { Stomach disorder, consti- } \\
\text { pation, digestive tract dis- } \\
\text { comfort, heartburn, aches, } \\
\text { indigestion }\end{array}$ & Whole fruit, pulp oil, and leaves are prepared as a decoction. & \\
\hline Dysentery/anaemia & A bark decoction is taken. & \\
\hline Leprosy & Root/root bark extracts are used. & \\
\hline
\end{tabular}

Owo people boil the leaves with locust bean (Parkia biglobosa (Jacq.) R. Br. ex G. Don) leaves and use the result to prevent and manage hypertension (èjè ríru - Yoruba). A leaf decoction is in employ for treating internal body heat (ooru inú); general weakness of the body (òrèrè) as well as for relaxation of muscles, especially in debilitated adults. The leaf decoction can be used for the treatment of general body weakness and pains and for high fever. It is also applied directly to relieve toothaches and earaches. The leaves or bark are boiled with elephant grass (Pennisetum purpureum Schumach.) for treatment of malaria. The leaves are used in the herbal preparation of agbo, a popular local medicine for treatment of stomach upset, malaria, and several other conditions. Local midwives compose formulations with the leaves and other materials to ease labor and aid safe birth delivery. The leaves or bark are boiled and administered to nursing mothers to relieve lactating pain. A leaf concoction is ingested for treatment of digestive tract discomforts.

Fruit: The fruit acts as a mild antacid to help digestion, however, eating too much of it could lead to purging.

Oil: Oil extracted from the fruit is used for the treatment and prevention of peptic ulcer and high blood pressure. Oil from its pulp is compounded with other materials as a skin lotion believed to smooth the skin and form a protective coating against sunlight. Pulp oil is usually mixed with other traditional oils; such as palm oil and applied topically to relieve general pains, stiffness and cramps as well as to treat cutaneous conditions.

Seeds: The dried powdered seeds are taken as tea for the treatment of stress.

Roots: Among the people of lyin town, the roots of $D$. edulis are known to treat beriberi and rickets when boiled with some other herbs and administered orally.
Bark: A bark decoction is used for treatment of dysentery and anemia. The decoction is also used as a gargle or mouthwash, for tonsillitis, and general oral hygiene (Ajibesin et al. 2008, Burkill 1985, Igoli et al. 2005). Extracts from the root/bark are administered for treatment of leprosy. The bark is ground and mixed with palm kernel oil for healing injuries.

Resin: Among the people of Ikereku Ikija the stem resin (exudates) is medicinal and is applied to treat ecto-parasitic infestations and infections (e.g., ticks and chiggers; ringworm, craw-craw) as well for dressing cuts, bruises and wounds (Dalziel 1937, Hutchinson et al. 1963, Okwu \& Nnamdi 2008). Exudates are used as thickeners in traditional drugs and cosmetics. This agrees with earlier reports by Ekpa, (1993) and Ayuk et al. (1999).

\section{Religious/Spiritual Uses}

Yorubas believe that the sweet scent from burned parts of $D$. edulis (stem exudates, leaves bark and root) wards away evil spirits (Sofowora 2008) particularly, around ill or ill-disposed persons, and during spiritually "tense" periods such as deaths or annual festivals/prayers. Hence the resin exudates, bark or roots are commonly burned as incense.

Worshipers and priests of local deities consider the plant "clean" and thus they routinely use the leaves as wrappers for prayer materials and medicinal preparations. The leaves are used to wrap pieces of bamboo sticks and other items for prayers by the local idol priest as well as part of the materials for appeasing the gods for rain. The worshipers of Ifa in Owo town regard the plant as a highly prolific species (with numerous fruits), hence different parts (fruits, leaves, bark, small branches or roots) are included in several spiritual collections to draw its power of fruitfulness (Table 3 ). 


\section{Omonhinmin - Ethnobotany of Dacryodes edulis in Southern Nigeria 1: Practices and applications among the Yoruba speaking people}

Table 3. Application of Dacryodes edulis (G. Don) H.J. Lam parts for spiritual and cultural engagements in the Yorubaspeaking areas of Southwest Nigeria.

\begin{tabular}{|c|c|c|c|}
\hline \multicolumn{2}{|c|}{ Uses } & Parts and prepration & Citation \\
\hline \multirow{5}{*}{ 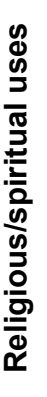 } & Incense - ward off evil spirits & Roots/bark are burned as incense. & Sofowora 2008 \\
\hline & $\begin{array}{l}\text { Lighting - lamp oil or bush } \\
\text { candle }\end{array}$ & Resin exudates are mixed with oil. Pulp is used to produce oil. & \\
\hline & Packing/wrapping leaves & $\begin{array}{l}\text { Leaves are used as wrappers for prayers/ worship materials by } \\
\text { local ifa (idol) practitioners and worshipers. }\end{array}$ & \\
\hline & Festivals & $\begin{array}{l}\text { Used as a sign of fruitfulness - prolific plants (with numerous } \\
\text { fruits). }\end{array}$ & \\
\hline & Udiroko festival & $\begin{array}{l}\text { Villagers whip themselves uncontrollably during the festival with } \\
\text { the branches for spiritual cleansing. }\end{array}$ & \\
\hline \multirow{8}{*}{ 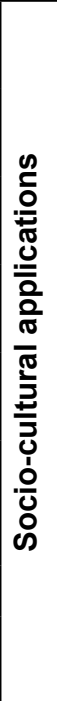 } & New yam festival & $\begin{array}{l}\text { Fruits are eaten and leaves are exchanged as an emblem of } \\
\text { bountiful harvest. }\end{array}$ & \\
\hline & Odun agbado festival & $\begin{array}{l}\text { The best of the fruits in the land are served to the governing } \\
\text { council of the area. }\end{array}$ & \\
\hline & Igogo festival & $\begin{array}{l}\text { Masquerade dancers use a fresh bunchy branch of the plant as } \\
\text { a symbol of peace. }\end{array}$ & \\
\hline & $\begin{array}{l}\text { Seasonal ljebu ijesha } \\
\text { festival }\end{array}$ & Fruits are eaten and shared among the youth. & \\
\hline & $\begin{array}{l}\text { Naming and religious } \\
\text { ceremonies }\end{array}$ & While in season, softened fruit is presented to welcome guest. & \\
\hline & $\begin{array}{l}\text { Marriage/marital } \\
\text { discussion }\end{array}$ & $\begin{array}{l}\text { Fruit is part of gift packages presented to the bride/bride's fam- } \\
\text { ily during the engagement ceremony to symbolize fruitfulness. } \\
\text { Fruits are commonly served in wedding ceremonies. }\end{array}$ & \\
\hline & War/fracas settlement & The leaves when offered or accepted signify peace. & \\
\hline & Foreigners acceptance & $\begin{array}{l}\text { A custom for any foreigner is to present fruits as part of offered } \\
\text { gifts. }\end{array}$ & \\
\hline
\end{tabular}

\section{Festivals}

The fruits are eaten and leaves are exchanged during the New Yam festival as symbols of a bountiful harvest. The Abule Ishaga people eat the fruit with corn during the Odun Agbado festival. Among the people of Ikereku Ikija, the fruits are eaten in festivals as desserts; the best of the fruits in the land being served to the governing council of the area. The Atiba people include the fruits in their New Yam festival collections and gifts hampers. During the seasonal ljebu ljesha festival, the fruits are shared among the youths. During the Igogo festival in Owo town, masquerade participants dance holding a fresh bunchy branch of the plant as an insignia of peace and fruitfulness. During the Udiroko festival, villagers whip themselves uncontrollably with the branches to achieve spiritual cleansing.

\section{Weddings}

The fruits are commonly served in wedding ceremonies. The ljebu Ode people; present the softened fruits in naming and religious ceremonies to welcome guests. In lyere
- Owo village, when the fruit is in season, it is usually included within the hamper that the groom's family offers to the bride's family during engagement ceremonies. It symbolizes a wish for fruitfulness of the bride. Among the people of Ikereku Ikija it is a medium of exchange in marital or intending marriage issues. Offer of the fruits from intending bride's family to the visiting groom's family marks signs of acceptance and welcome. Among the Egba people of Egbaland, the fruit is included as part of the hamper presented to the family of a woman when seeking her hand in marriage. Among the Igbodu people the fruit is presented alongside other fruits as gift to the bride's family during marriage negotiations (Table 3 ).

Generally, the fruit is of considerable importance in the economy of the people. It is traded extensively during its fruiting season to raise sizeable incomes. In Lagos Island, trees are rarely planted and where they are, they often serve for ornamental and shade plants. In llesa village, the trees are planted in homesteads for shade and fire wood. 
Presentation of fruit marks the general acceptance of someone. The Owu ljebu people consider the plant a symbol of prosperity and offering it to a visitor as a sign of good hospitality. The Abule Ishaga people view the plant as a serene plant, due to it shade-giving attributes. The leaves when offered or accepted signify peace during war or fracases among individuals (Table 3). To the ljebu-Igbo people, the fruit is considered a veritable part of the acceptance gift pack offered by foreigners to people of the community. This is because the plant was first introduced into the community by "Igbo" settlers (Easterners). They gave gifts (including the fruit) to the ruler of the community, now it is a custom for any foreigner to present $D$. edulis fruit as part of the gifts offered while seeking to live among the people, or in other occasions that demand such gifts.

\section{Domestication, Environmental Development and Improvement}

The Yoruba people, as farmers, are most known for two cash crops; kola (Cola sp.) and cocoa (Theobroma cacao L.). These species define the economy of the region. $D$. edulis is considered an introduced plant by the Yoruba. Though its use is wide spread among the tribe, cultivation is however restricted to communities close to the southern borders. In such communities, stands of the plants are found around homes, in homesteads, maintained fallow farmlands and to a high degree in cocoa plantations, rarely in the wild. Its prevalence in cocoa plantations is hinged on the high value for its leaf litter as manure and the shade it provides.

In places like ljebu Ode, Igbodu and Owo, there seems to be an increasing cultivation of $D$. edulis westward. A number of young trees most of which are yet to fruit or are in their early fruiting stage were noticed. These stands of $D$. edulis were mostly around homes rather than in plantations and have become common among horticultural plants around old and new properties in these areas. Home owners reasoned that they planted the species around their homes so they could give it the attention it requires while growing, readily engage it for spiritual and cultural attachments, and to take advantage of the benefit of shade and income it will provides when mature. However, in places like Igede, Alausa, Aiyetoro-Gbede further west and north, cultivation of the species was not recorded.

The plant is certainly undergoing domestication, though still for subsistence, because the farmers reasonably hope for improvement of their cocoa and kola farms rather than replace the plantations with $D$. edulis. The reasons they offer among several is the poor market value of $D$. edulis when compared to cocoa and kola, high perishable state of the fruit after harvest and the poor storage facilities present to manage $D$. edulis fruits. However, whether the increased cultivation translates to improved genetic diversity as reported by Leakey et al. (2004) is not sup- ported by the present findings. This is because most of the new stands recorded where of the large size fruit type parvicarpa variety, commonly called among the people onitsha fruits (referring to a south eastern popular market). This shows a preference for a particular variety, prevalent in the eastern part of Southern Nigeria uncommon to the Yoruba area except by trade. Conversely, the majority of older tress hitherto cultivated are the small sized fruit variety (i.e., var. edulis). The present trend may ultimately result in genetic erosion of a particular aspect of the diversity of the species in the area.

The increase cultivation of $D$. edulis, with a further spread toward the interior, is of environmental importance as it will contribute to the ecological upgrading of the farm system, where this increased cultivation extends to the plantations. Alternatively, where the increased cultivation translate to improved income, then excessive reliance on woody and non-woody forest resources may subside and thus the environmental degradation that accompany such activities. However, the degree of importance placed on the species by the tribal people ensures that domestication and cultivation will continue and the trend of cultivation restricted to the home and homesteads, will guarantee the species will continue to enjoy "protection" status and thus contribute to the environmental health of the communities with considerable populations of the species.

Efforts to improve this species will probably be successful where preferences of the indigenous people, who have managed the plants for the prevailing attribute diversity, are directed at participation of tribal people or use of ethnobotanical information for species management. Participatory improvements of $D$. edulis will thus be possible where the medicinal, spiritual, as well as economic importance of the plant to the Yoruba people is integral into improvement programs of researchers and agencies alike. Information as contained in the present study will thus be essential to such improvement programs.

\section{Conclusion}

Though considered introduced, $D$. edulis has found much acceptance and hence application in the various aspects of lives of Yoruba speaking people of Nigeria. The wide range of uses and localization of names in some areas testify to the degree of integration the taxon has enjoyed within the Yoruba ethnographical area. This information will be of importance for domestication, improves production and other socioeconomic efforts that the plant may be engaged in future at whatever level. Similarly, this present study will be useful in understanding the spread pattern of the species, and the forces driving the domestication, away from its area of endemism in South east and South south Nigeria. 


\section{Omonhinmin - Ethnobotany of Dacryodes edulis in Southern Nigeria 1: Practices and applications among the Yoruba speaking people}

\section{Literature Cited}

Ajiwe V.I.E., C.A. Okeke, B. Nnabuike, G.A. Ogunleye \& E. Flebo. 1997. Application of oils extracted from African stare apple (Chrysophyllum africanus), horse eye bean (Mucuna sloane) and African pear (Dacryodes edulis) seeds. Bioresoures Technology 59(2-3):259-261.

Ajibesin, K.K. 2011. Dacryodes edulis (G.Don) H.J. Lam: A review on its medicinal, phytochemical and economic properties. Research Journal of Medicinal Plant 5(1):3241.

Ajibesin, K.K., B.J. Ekpo, D.N. Bala, E.E. Essien, \& S.A. Adesanya. 2008. Ethnobotanical survey of Akwa lbom state of Nigeria. Journal of Ethnopharmacology 115:387408.

Awono, A., O. Ndoye, K. Schreckenberg, H. Tabuna, F. Isseri \& L. Temple. 2002. Production and marketing of Safou (Dacryodes edulis) in Cameroon and internationally: Market development issues. Forest, Trees and Livelihoods 12:125-147.

Ayuk, E.T., B. Duguma, S. Franzel, J. Kengue, M. Mollet, T. Tiki-Manga \& P. Zekeng. 1999. Uses, management and economic potentials of Dacryodes edulis (Burseraceae) in the humid lowlands of Cameroon. Economic Botany 53:292-301.

Burkill, H.M. 1985. The Useful Plants of West Tropical Africa 2nd Edition, Volume 1. Royal Botanic Gardens, Kew.

Cotton, C.M. 1996. Ethnobotany: Principles and applications. John Wiley and Sons, Chichester, United Kingdom.

Dalziel, J.M. 1937. Flora of West Tropical Africa. Crown Agents for Overseas Government, London.

Ekong, D.E.U. \& J.I. Okogun. 1969. Terpenoids of Dacryodes edulis. Phytochemistry 8:669-671.

Ekpa, O. 1993. The use of Raphia hookeri and Pachylobus edulis in cosmetic formulation. Discovery Innovation 5:313-316.

Hutchison, J., J.M. Dalziel, F.N. Herpper. 1963. Flora of West Africa II. Macmillian Publishers Ltd., Lagos.

IFAD. 1999. The International Centre for Research In Agroforestry (ICRAF): Diversification Of Smallholder Farming Systems In West And Central Africa Through Cultivation Of Indigenous Trees. Executive Board - Sixty-Seventh Session Rome, 8-9 September 1999. EB 99/67/R.20 - Agenda Item 10(a).
Igoli, J.O., O.G. Ogaji, T.A. Tor-Anyiin, \& N.P. Igoli. 2005. Traditional medicine practice amongst the Igede people of Nigeria. Part II. African Journal of Traditional, Complementary and Alternative Medicines 2(2):134-152.

Ikhuoria, E. \& U.M. Maliki. 2007. Characterization of avocado pear (Persea americana) and African pear (Dacryodes edulis) extracts. African Journal of Biotechnology 6(7):950-952.

Jirovetz, L., G. Buchbauer, A.S. Stoyanova, E.V. Georgiev, S.T. Damianova. 2003. Composition, quality control and antimicrobial activity of the essential oil of long time stored dill (Anethum graveolens L.) seeds from Bulgaria. Journal of Agricultural and Food Chemistry 18(51):38543857.

Kapseu, C. \& C. Tchiegang. 1996. Composition de l'huile des fruits de deux cultivars de safou au Cameroun. Fruits 51:185-191.

Kargioglu, M., S. Cenkci, A. Serteser, N. Evlioyaoglu, M. Konuk, M.S. Kok \& Y. Bagci. 2008. An ethnobotanical survey of Inner-West Anantolia, Turkey. Human Ecology 36:763-777.

Kinkéla, T., R. Kama-Niamayoua, D. Mampouya \& T. Silou. 2006. Variations in morphological characteristics, lipid content and chemical composition of safou (Dacryodes edulis (G. Don) J. Lam. according to fruit distribution: A case study. African Journal of Biotechnology 5(12):12331238.

Lange, D. 2004. Dying and rising God. Pp 343-376 in Ancient Kingdoms of West Africa: Africa-centred and Canaanite-Israelite perspectives. Edited by D. Lange. Verlag J. H. Röll GmbH, Dettelbach, Germany.

Leakey, R.R.B. \& D.O. Ladipo. 1996. Trading on genetic variation - fruits of Dacryodes edulis. Agroforestry Today $8(2): 16-17$.

Leakey, R.R.B. 1999. Potential for novel food products from agroforestry trees: A review. Food Chemistry 66:114.

Martin, G.J. 1995. Ethnobotany: A methods manual. Chapman and Hill, London

Neuwinger, H.D. 2000. African traditional medicine. Pp. 406-408 in A Dictionary of Plant Use and Applications. Medpharm Scientific Publishers, Stuttgart, Germany.

Obasi, N.B.B. \& N.P. Okoli 1993. Nutritional constituents of the seeds of African pear, Dacryodes edulis. Food Chemistry 46(3):297-299. 
Okafor, J.C. 1983. Varietal delimitation in Dacryodes edulis (G. Don) H.J. Lam. (Burseraceae). International Tree Crops Journal 2:255-265.

Okwu, D.E. \& F.U. Nnamdi. 2008. Evaluation of the chemical composition of Dacryodes edulis and Raphia hookeri Mann and Wendl exudates used in herbal medicine in south eastern Nigeria. African Journal of Traditional, Complementary and Alternative Medicines 5:192-200.

Omoti, U. \& D.A. Okiy. 1987. Characteristics and composition of the pulp oil and cake of the African pear, Dacryodes edulis (G. Don) H. J. Lam. Journal of the Science of Food and Agriculture 38:67-72.

Ozgen, U., Y. Kaya \& M. Coskun. 2004. Ethnobotanical studies in the villages of the District of llica (Province Erzurum) Turkey. Economic Botany 58:691-696.
Sofowora, L.A. 2008. Medicinal Plants and traditional Medicine in Africa. 2nd Edition. Spectrum Book Ltd., lbadan, Nigeria.

Simons, A.J. 1996. ICRAF's strategy for domestication of indigenous tree species. Pp. 8-22 in Domestication and Commercialization of Non-Timber Forest Products in Agroforestry Systems, Non-Wood Forest Products 9. Edited by R.R.B. Leakey, A.B. Temu, M. Melnyk \& P. Vantomme. Food and Agriculture Organization of the United Nations, Rome, Italy.

Simons, A.J. \& R.R.B. Leakey. 2004. Tree domestication in tropical agroforestry. Agroforestry Systems 61:167-181.

Waruhiu, A.N., J. Kengue, A.R. Atangana, Z. Tchoundjeu \& R.R.B. Leakey. 2004. Domestication of Dacryodes edulis: 2. Phenotypic variation of fruit traits in 200 trees from four populations in the humid lowlands of Cameroon. Journal of Food, Agriculture and Environment 2(1):340346. 